\title{
TNF-a augmented Porphyromonas gingivalis invasion in human gingival epithelial cells through Rab5 and ICAM-1
}

Yoshiko Kato ${ }^{1,2}$, Makoto Hagiwara', Yuichi Ishihara ${ }^{2}$, Ryutaro Isoda', Shinsuke Sugiura², Toshinori Komatsu', Naoyuki Ishida ${ }^{1,2}$, Toshihide Noguchi ${ }^{2}$ and Kenji Matsushita ${ }^{1^{*}}$

\begin{abstract}
Background: Tumor necrosis factor alpha (TNF-a) plays a central role in the initiation and maintenance of immune responses to periodontopathic bacteria. However, excess TNF-a leads to dysregulated immune responses and progression of periodontitis. Porphyromonas gingivalis ( $P$. gingivalis) invades gingival epithelial cells and then multiplies and survives for a long period. Additionally, increment of TNF-a in periodontal sites is associated with a high prevalence of gram-negative anaerobes such as $P$. gingivalis. However, it has not been determined whether TNF- $a$ affects invasion of $P$. gingivalis in periodontal tissues.

Results: We examined the effect of TNF-a on invasion of $P$. gingivalis in gingival epithelial cells and clarified the mechanism by which TNF-a augments invasion of $P$. gingivalis. Invasion of $P$. gingivalis into Ca9-22 cells was augmented by stimulation with TNF-a and it was inhibited by treatment with an antibody to TNF receptor-1. TNF-a increased production of ICAM-1, and P. gingivalis invasion was inhibited by an antibody to ICAM-1 in Ca9-22 cells. Silencing of Rab5 mRNA inhibited $P$. gingivalis invasion. Furthermore, the JNK inhibitor SP600125 inhibited invasion of $P$. gingivalis and also decreased the active form of Rab5 in Ca9-22 cells.

Conclusion: TNF-a augments invasion of $P$. gingivalis in human gingival epithelial cells through increment of ICAM-1 and activation of Rab5. These phenomena may contribute to persistent infection of $P$. ginigvalis and prolongation of immune responses in periodontal tissues.
\end{abstract}

Keywords: Porphyromonas gingivalis, Endocytosis, TNF-a, Rab5, ICAM-1, Persistent infection

\section{Background}

Chronic periodontitis is initiated by a bacterial biofilm commonly called dental plaque, which initiates inflammation that affects the supporting structures of teeth, leading to bone and eventually tooth loss. The development of periodontitis is a multifactorial process involving interactions between the host and microorganisms that colonize the gingival sulcus. Porphyromonas gingivalis is a gram-negative anaerobe of dental plaque and it has been strongly implicated in the initiation and progression of periodontal disease and possesses a sophisticated array of virulence factors, including those that

\footnotetext{
* Correspondence: kmatsu30@ncgg.go.jp

${ }^{1}$ Department of Oral Disease Research, National Center of Geriatrics and Gerontology, Obu, Aichi 747-8511, Japan

Full list of author information is available at the end of the article
}

allow the bacterium to adhere to and invade host epithelial cells [1-5]. P. gingivalis invasion is accomplished by manipulating host signal transduction and remodeling of the cytoskeletal architecture. However, the molecular mechanisms used by $P$. gingivalis to facilitate internalization are only partially understood.

Intracellular bacterial pathogens have evolved highly specialized mechanisms to enter and survive intracellularly within their eukaryotic hosts. Rabs play an essential role in both endocytic and exocytic traffic in eukaryotic cells [6]. Rab5, one of the most studied Rab proteins in recent years, is involved in early steps of the endocytic process. Rab5 regulates intracellular membrane trafficking of several pathogens, including Salmonella enterica serovar Typhimurium [7-9], Mycobacterium spp [10], and Listeria monocytogenes [11]. Rab5 may also mediate 
internalization of $P$. gingivalis in host cells; however, little is known about the role of Rab5 in P. gingivalis invasion.

TNF- $\alpha$ is a potent pleiotropic proinflammatory cytokine and is released by a variety of different cell types in response to various stimuli, including bacteria, parasites, viruses, cytokines and mitogens. TNF- $\alpha$ is involved in systemic and local inflammation due to stimulation of different signal transduction pathways, inducing the expression of a broad range of genes. TNF- $\alpha$ regulates a host response to infection; on the other hand, inappropriate expression of TNF- $\alpha$ has detrimental effects for the host. Deregulation of TNF- $\alpha$ has been implicated in the pathogenesis of numerous complex diseases, including periodontitis [12-14], cardiovascular diseases $[15,16]$, diabetes mellitus $[17,18]$, autoimmune diseases $[19,20]$, and cancer $[21,22]$. Clinical studies have shown an upregulation of TNF- $\alpha$ in periodontitis, e.g., in gingival crevicular fluid [23], in gingival tissues [24], and in plasma and serum [14,25]. TNF- $\alpha$ was shown to have an impact on different biological processes, including induction of inflammatory mediators, such as matrix metalloproteases (MMPs), cytokines, chemokines and prostaglandins [26], endothelial cell activation and endothelial-leukocyte interactions [27], monocyte adhesion [28], mediating bone remodeling [29], and oxidative processes [30]. P. gingivalis induces highest levels of TNF- $\alpha$ expression, followed by IL-1 and IL-6 [31]. However, we have no information on whether TNF- $\alpha$ affects invasion of $P$. gingivalis in periodontal tissues. In the present study, we examined the effect of TNF- $\alpha$ on invasion of $P$. gingivalis in gingival epithelial cells and clarified the molecular mechanism by which TNF- $\alpha$ augments invasion of $P$. gingivalis.

\section{Results}

TNF-a augments invasion of $P$. gingivalis in gingival epithelial cells

We first examined the effect of TNF- $\alpha$ on invasion of $P$. gingivalis in Ca9-22 cells. The cells were treated with $10 \mathrm{ng} / \mathrm{ml}$ of TNF- $\alpha$ for $3 \mathrm{~h}$ and were then incubated with $P$. gingivalis $(\mathrm{MOI}=100)$ for $1 \mathrm{~h}$. Invasion of the cells by $P$. gingivalis was determined by an invasion assay. Invasion of Ca9-22 cells by $P$. gingivalis was observed without TNF- $\alpha$ pretreatment. However, the invasion was significantly increased by stimulation with TNF- $\alpha$ (Figure 1A). We also observed localization of intracellular $P$. gingivalis in the cells by using a confocal laser scanning microscope. Z-stack image of the cells shows the intracellular localization of $P$. gingivalis. Intracellular $P$. gingivalis was increased by stimulation with TNF- $\alpha$, although a small amount of $P$. gingivalis was found without TNF- $\alpha$ pretreatment (Figure 1B).

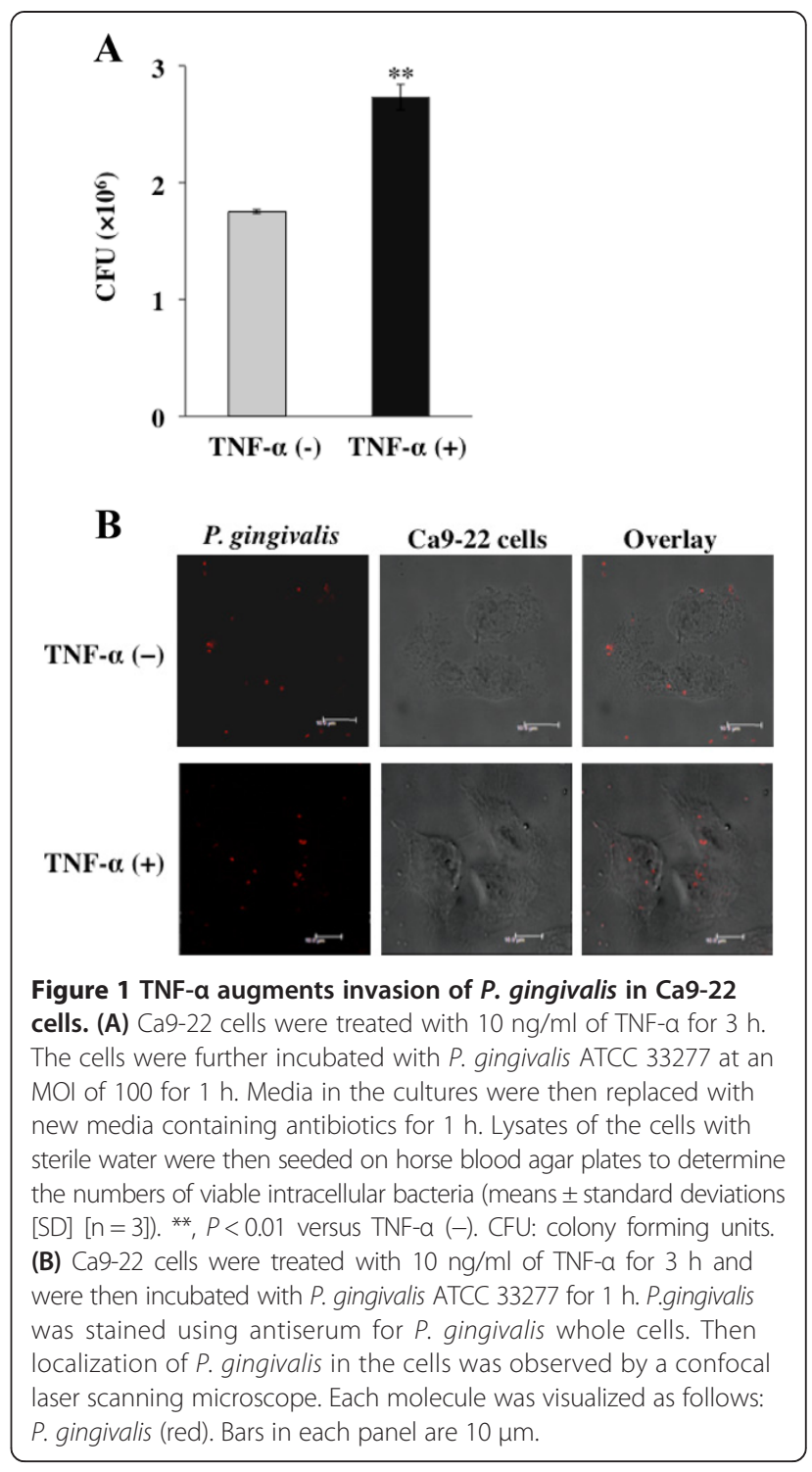

TNF-a-augmented invasion of $P$. gingivalis is mediated by TNF receptor-I

The biological effects of TNF- $\alpha$ are transmitted via two distinct membrane receptors, TNFR-I and TNFR-II [32,33]. To determine which type of TNFR mediates $P$. gingivalis invasion in Ca9-22 cells, we examined the effects of neutralization of TNFRs on the TNF- $\alpha$ augmented invasion of $P$. gingivalis. We first examined the expression of TNFR-I and TNFR-II in Ca9-22 cells by Western blotting. The cells expressed TNFR-I but not TNFR-II (Figure 2A). We next examined the effects of a neutralizing anti-TNFR-I mAb on the TNF- $\alpha$-induced invasion of $P$. gingivalis in Ca9-22 cells. The cells were preincubated with a mouse monoclonal antibody to TNFR-I for $1 \mathrm{~h}$. Then the cells were treated with TNF- $\alpha$ prior to addition of $P$. gingivalis. The anti-TNFR-I antibody exhibited a significant inhibitory effect on the invasion of $P$. 


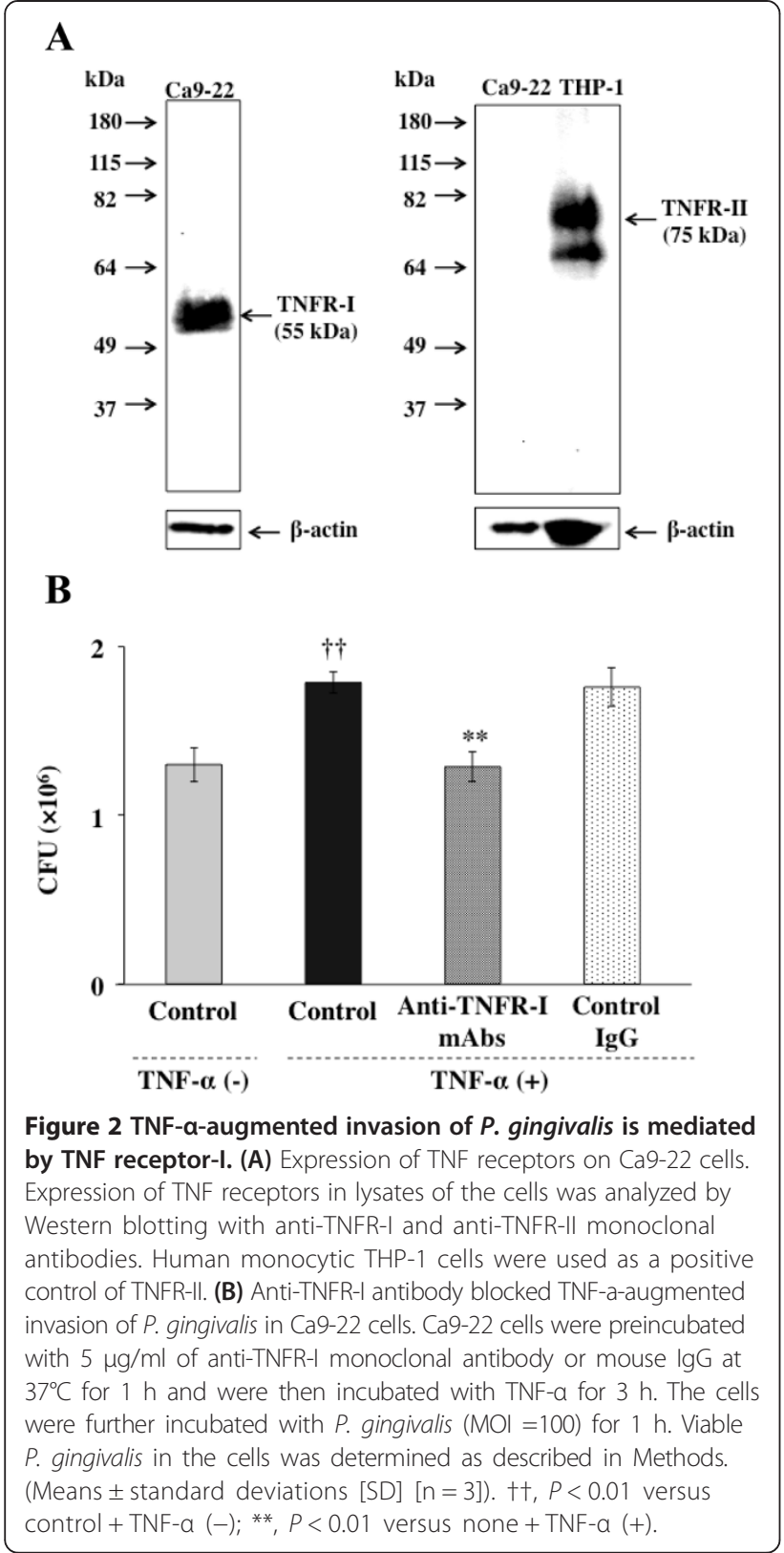

gingivalis in Ca9-22 cells (Figure 2B). In contrast, a control mouse IgG antibody did not prevent the augmentation of $P$. gingivalis invasion by TNF- $\alpha$.

\section{TNF-a augments invasion of $P$. gingivalis through NF-KB and MAPK pathways}

To determine whether mRNA synthesis and protein synthesis were required for $P$. gingivalis invasion, Ca9-22 cells were preincubated with $1 \mu \mathrm{g} / \mathrm{ml}$ of the RNA polymerase II inhibitor actinomycin D or the protein synthesis inhibitor cycloheximide for $1 \mathrm{~h}$ and were then incubated with TNF- $\alpha$ prior to addition of $P$. gingivalis. Actinomycin D and cycloheximide exhibited significant inhibitory effects on the invasion of P.gingivalis into Ca922 cells (Figure 3 ). The PI3K/Akt signaling pathway is commonly initiated by transmembrane receptor signaling and controls cellular phagocytic responses through multiple downstream targets that regulate actin polymerization and cytoskeletal arrangements at the target site [34]. In addition, TNF- $\alpha$ activates the PI3K/AKT signaling pathway [35]. Therefore, we examined the relationship between PI3K activity and $P$. gingivalis invasion in Ca9-22cells. Ca9-22 cells were preincubated with wortmannin at $37^{\circ} \mathrm{C}$ for $3 \mathrm{~h}$ and were then incubated with TNF- $\alpha$. Treatment with wortmannin also exhibited significant inhibitory activity towards the invasion of $P$. gingivalis enhanced by TNF- $\alpha$ (Figure 4). Several lines of evidence indicate that cellular effects of TNF- $\alpha$ were elicited through the activation of MAPK and NF- $\mathrm{B}$ pathways. To explore the contribution of MAPK and NF- $\mathrm{KB}$ to TNF$\alpha$-augmented invasion of $P$. gingivalis, we examined whether $P$. gingivalis is able to invade Ca9-22 cells in the presence or absence of MAPK inhibitors and an NF-kB inhibitor. Ca9-22 cells were preincubated with a p38 inhibitor (SB 203580, $5 \mu \mathrm{M}$ ), JNK inhibitor (SP 600125, $1 \mu \mathrm{M}$ ), ERK inhibitor (PD 98059, $5 \mu \mathrm{M}$ ) or NF-kB inhibitor (PDTC, $5 \mu \mathrm{M}$ ) for $1 \mathrm{~h}$ and were then incubated with TNF- $\alpha$ prior to addition of $P$. gingivalis. SB 203580 and SP 600125 exhibited significant inhibitory effects on the invasion of $P$. gingivalis into Ca9-22 cells (Figure 5A). In contrast, PD 98059 did not prevent the invasion of $P$. gingivalis augmented by TNF- $\alpha$. PDTC also exhibited significant inhibitory activity towards the

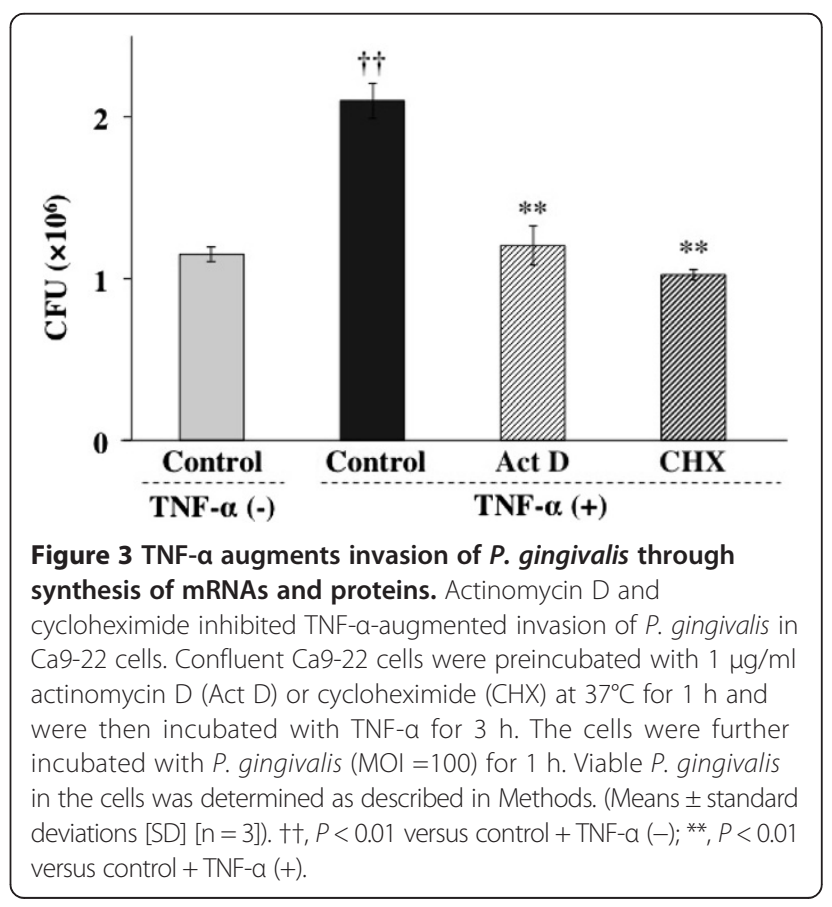




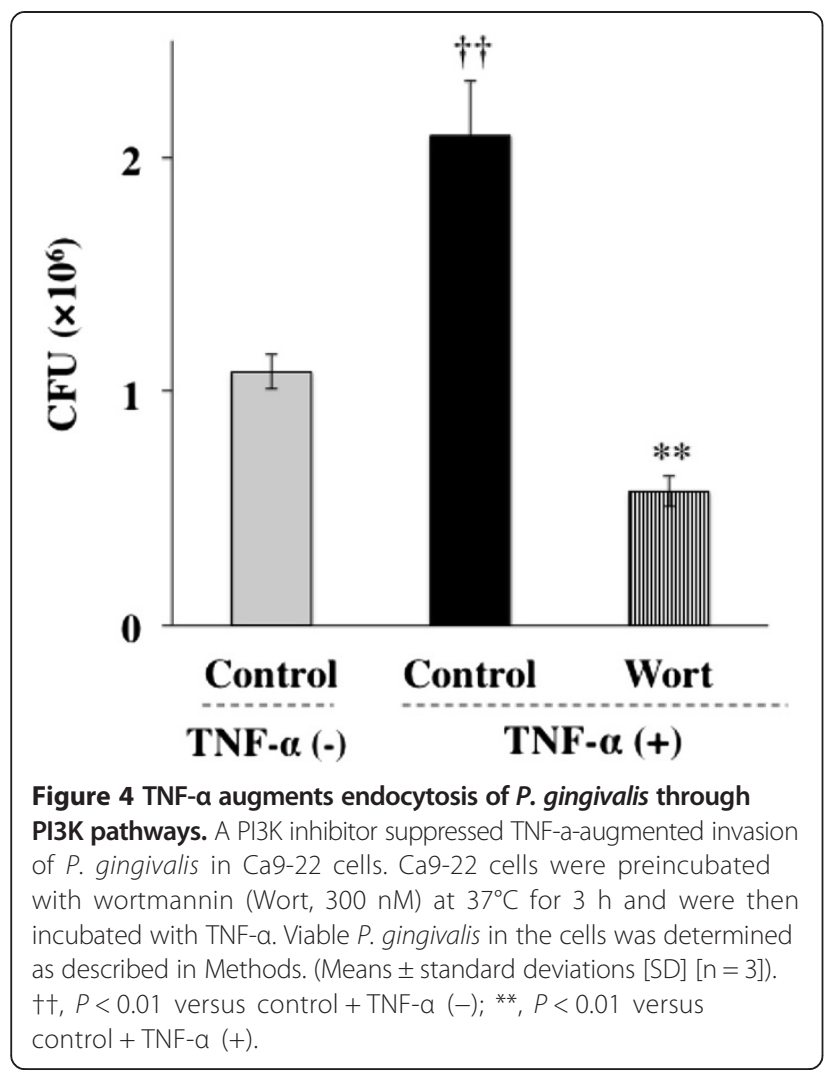

invasion of $P$. gingivalis enhanced by TNF- $\alpha$ (Figure 5B). These results suggest that TNF- $\alpha$ augmented invasion of $P$. gingivalis is mediated by $\mathrm{p} 38$ and JNK pathways and activation of $\mathrm{NF}-\mathrm{kB}$.

\section{ICAM-1 mediates invasion of $P$. gingivalis}

Expression of ICAM-1 is required for invasion of some bacteria in KB cells [36]. To determine whether ICAM-1 affects $P$. ginigvalis invasion into cells, we first examined co-localization of $P$. gingivalis with ICAM-1 in cells. Ca9-22 cells were incubated with $P$. gingivalis, and localization of ICAM-1 and $P$. ginigvalis in the cells was observed by a confocal laser scanning microscope. ICAM-1 strongly expressed around the cell surface was partially co-localized with $P$. gingivalis in the cells (Figure 6A). We also examined the expression of ICAM-1 in TNF- $\alpha$-treated Ca9-22 cells. Ca9-22 cells were treated with or without TNF- $\alpha$ for $3 \mathrm{~h}$. The cells were lysed and expression of ICAM-1 was analyzed by Western blotting. ICAM-1 was expressed in Ca9-22 cells without TNF- $\alpha$ stimulation (Figure 6B). However, TNF- $\alpha$ increased the expression of ICAM-1 in the cells. We next examined whether ICAM-1 is associated with invasion of $P$. gingivalis into the cells. Ca9-22 cells were treated with TNF- $\alpha$ for $3 \mathrm{~h}$, incubated with an antiICAM-1 antibody or a control IgG antibody for an
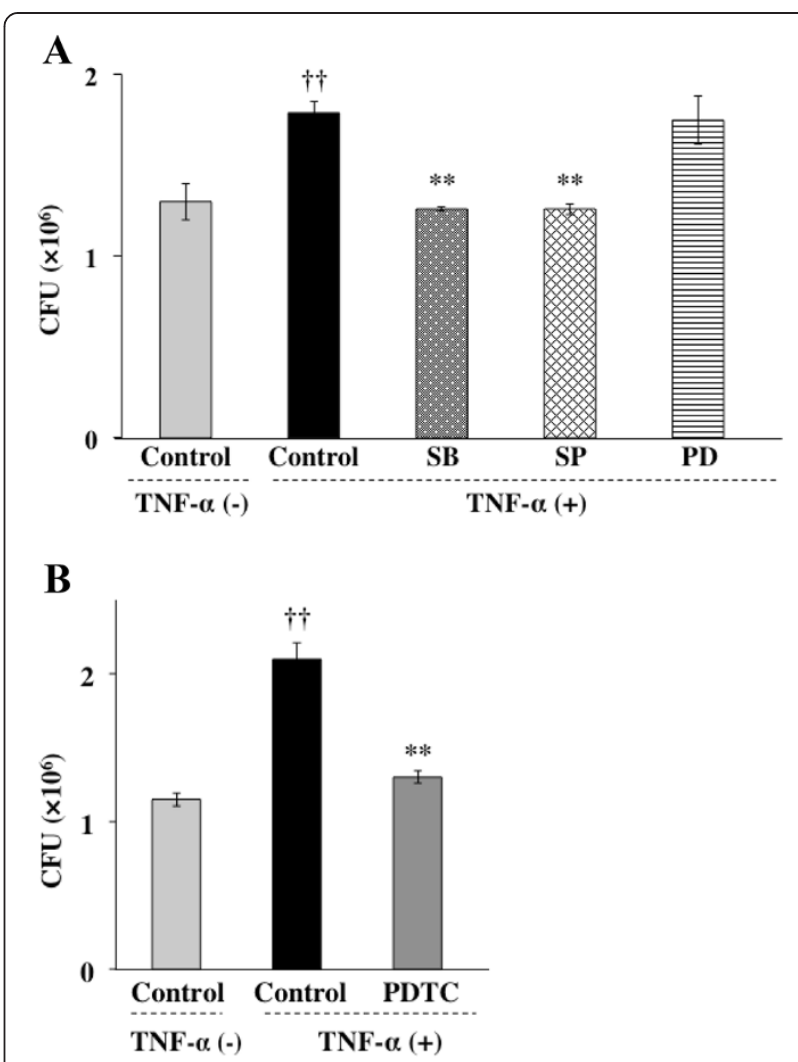

Figure 5 TNF- $\alpha$ augments invasion of $P$. gingivalis through NF-kB and MAPK pathways. (A) JNK and p38 inhibitors blocked TNF-a-augmented invasion of $P$. gingivalis in Ca9-22 cells. Confluent Ca9-22 cells were preincubated with MAP kinase inhibitors (p38 inhibitor (SB203580, $5 \mu \mathrm{M})$, JNK inhibitor (SP600125, $1 \mu \mathrm{M}$ ) and ERK inhibitor (PD98059, $5 \mu \mathrm{M})$ ) at $37^{\circ} \mathrm{C}$ for $1 \mathrm{~h}$ and were then incubated with TNF-a. Viable P. gingivalis in the cells was determined as described in Methods. (Means \pm standard deviations [SD] $[n=3]$ ). t+, $P<0.01$ versus control + TNF- $a(-)$; ${ }^{*}, P<0.01$ versus control + TNF-a (+). (B) NF-KB inhibitor suppressed TNF-a-augmented invasion of $P$. gingivalis in Ca9-22 cells. Ca9-22 cells were preincubated with an NF-KB inhibitor (PDTC, $5 \mu \mathrm{M}$ ) at $37^{\circ} \mathrm{C}$ for $1 \mathrm{~h}$ and were then incubated with TNF-a. Viable $P$. gingivalis in the cells was determined as described in Methods. (Means \pm standard deviations [SD] $[n=3])$. †t, $P<0.01$ versus control + TNF- $a(-) ;{ }^{* *}, P<0.01$ versus control + TNF-a $(+)$

additional $2 \mathrm{~h}$, and then incubated with $P$. gingivalis. Anti-ICAM-1 antibody suppressed invasion of $P$. gingivalis in the cells with or without TNF- $\alpha$ pretreatment (Figure $6 \mathrm{C}$ ). In contrast, $P$. gingivalis invasion was not prevented by control IgG. These results suggest that ICAM-1 is partially associated with invasion of $P$. gingivalis into Ca9-22 cells.

\section{Rab5 mediates endocytosis of $P$. gingivalis}

Several studies have shown that Rab5 regulates events in the fusion of bacteria-containing vacuoles and early endosomes [37-39]. Therefore, we investigated whether Rab5 mediates $P$. gingivalis invasion into cells. We first 


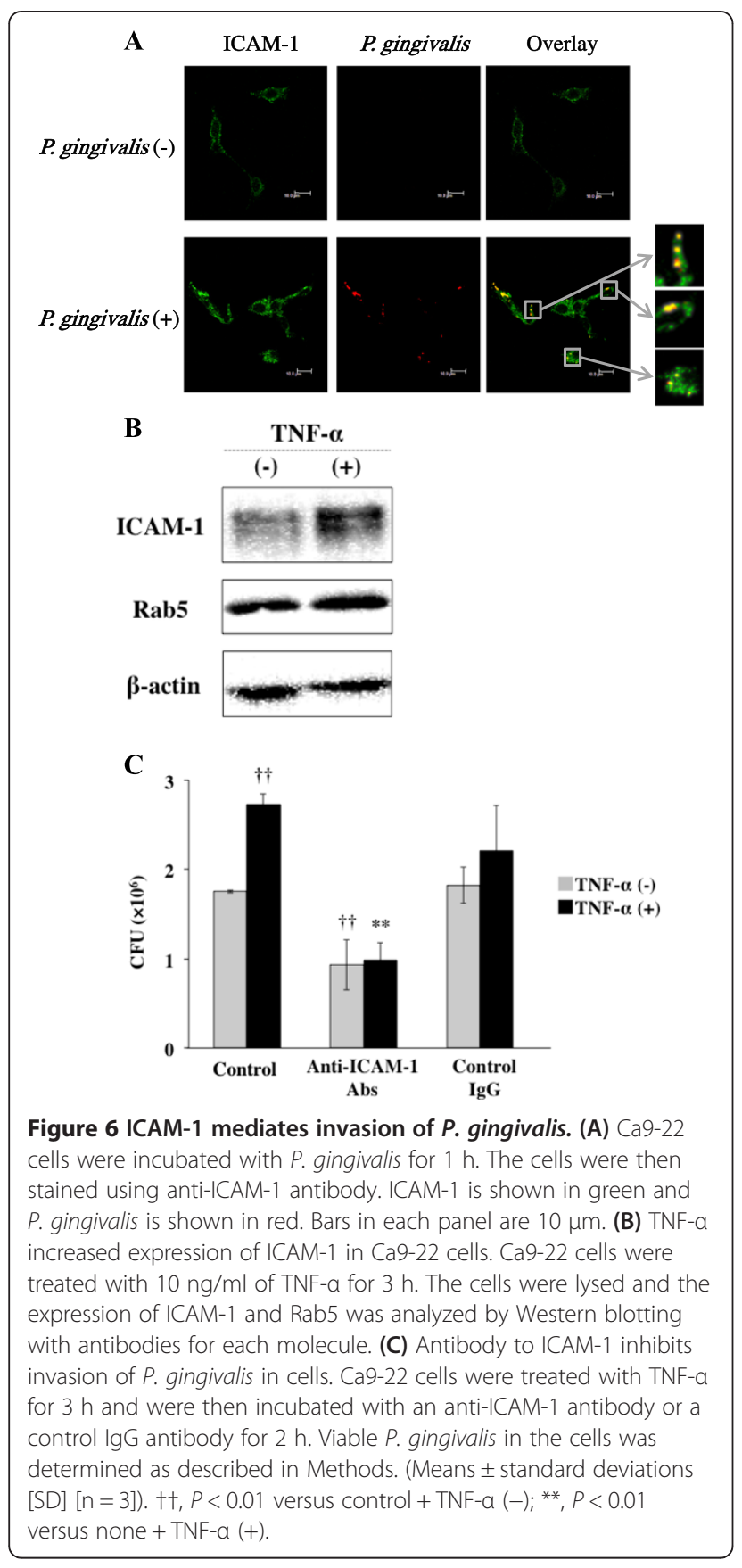

examined the expression of Rab5 in Ca9-22 cells by Western blotting. As shown in Figure 6B, Rab5 was expressed in Ca9-22 cells. However, the level of expression was not affected by TNF- $\alpha$. We next investigated the role of Rab5 in P. gingivalis invasion using an siRNA interference approach. Invasion assays were carried out following transfection of Rab5-specific siRNA at a concentration of $100 \mathrm{pmol}$ for $24 \mathrm{~h}$. Then expression of Rab5 in the cells was examined by Western blotting (Figure 7A). The Rab5 siRNA-transfected Ca9-22 cells were incubated with $P$. gingivalis for $1 \mathrm{~h}$. Internalization of $P$. gingivalis into the cells was reduced by silencing the Rab5 gene (Figure 7B). To determine whether the Rab5 affects $P$. ginigvalis invasion into cells, Ca9-22 cells expressing GFP-Rab5 were treated with $P$. gingivalis, and localization of Rab5 and P. ginigvalis in the cells was observed by a confocal laser scanning microscope. Transfected GFP-Rab5 was partially co-localized with $P$. gingivalis in the cells (Figure $7 \mathrm{C}$ ). These results suggest that Rab5 is partially associated with invasion of P. gingivalis into Ca9-22 cells.

\section{Overexpression of the active form of Rab5 increased invasion of $P$. gingivalis}

Rab5 proteins switch between two distinct conformations, an active state characterized by binding to GTP and an inactive state bound to GDP. To test whether the activity of Rab5 affects $P$. ginigvalis invasion into cells, Ca9-22 cells expressing fluorescent-labeled GFP alone (control), GFP-Rab5 (S34N) (constitutively inactive mutant), and GFP-Rab5 (Q79L) (constitutively active mutant) were treated with $P$. gingivalis, and localization of Rab5 and $P$. ginigvalis in the cells was observed by a confocal laser scanning microscope. Transfected GFPRab5 (Q79L) was co-localize with $P$. gingivalis in the cells (Figure 7D). In contrast, GFP-Rab5 (S34N) did not colocalize with $P$. gingivalis in the cells. We next transfected vectors expressing GFP alone, GFP-Rab5 (S34N) and GFP-Rab5 (Q79L) into Ca9-22 cells. The transfected cells were then treated with $P$. ginigvalis and the levels of invasion were compared among those cells. Internalization of $P$. gingivalis into cells was increased in Ca9-22 cells expressing GFP-Rab5 (Q79L) compared to that in Ca9-22 cells expressing GFP alone (Figure 7E). On the other hand, overexpression of GFP-Rab5 (S34N) suppressed invasion of $P$. gingivalis into the cells. These results suggest that the activity of Rab5 influences $P$. gingivalis invasion.

\section{TNF-a was associated with activity of Rab5 through the JNK pathway}

Several cytokines can control the activity of Rab5 to regulate the rate of endocytosis through activating the downstream signaling pathway. Therefore, we examined whether activation of Rab5 was affected by MAP kinases activated with TNF- $\alpha$ signals using a pull-down approach with a fusion protein that selectively binds GTPloaded Rab5 (GST-R5BD). The system selectively bound GTP-bound Rab5 (active form of Rab5). Ca9-22 cells were transfected with an expression vector with inserted GFP-Rab5 gene. The transfected cells were preincubated with MAP kinase inhibitors, including a p38 inhibitor (SB203580), JNK inhibitor (SP600125) and ERK inhibitor (PD98059), and were then incubated with TNF- $\alpha$. The 

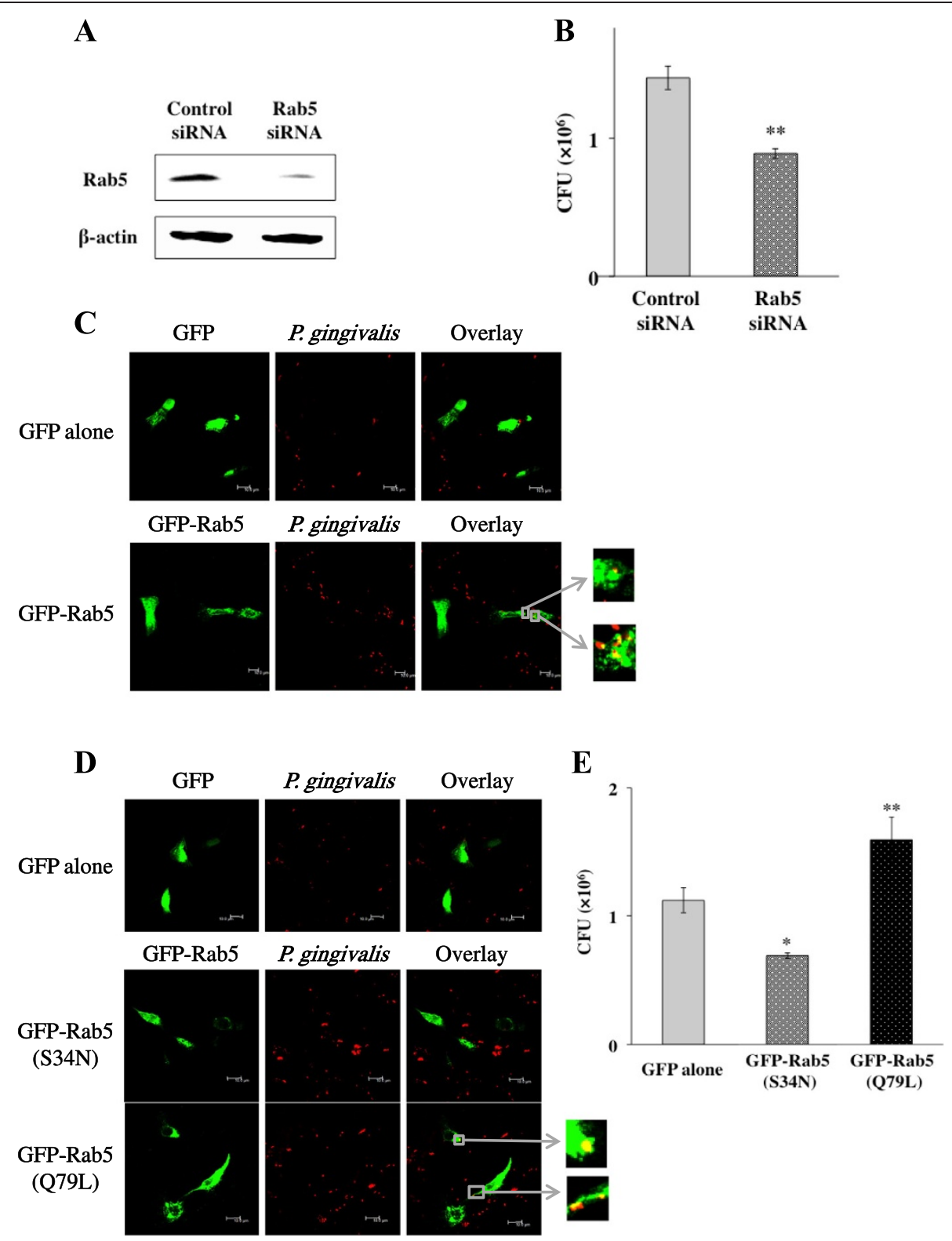

Figure 7 Rab5 mediates endocytosis of $\boldsymbol{P}$. gingivalis. (A) Ca9-22 cells were transfected with 100 pmol siRNA specific for Rab5 or control siRNA using Lipofectamine 2000 reagent, as described by the manufacturer. Then expression of Rab5 in the cells was examined by Western blotting. (B) Rab5 siRNA-transfected Ca9-22 cells were incubated with P. gingivalis for $1 \mathrm{~h}$. Viable $P$. gingivalis in the cells was determined as described in Methods. (Means \pm standard deviations [SD] $[n=3] .{ }^{* *}, P<0.01$ versus control siRNA. (C) Ca9-22 cells were transfected with expression vectors with inserted genes of GFP alone and GFP-Rab5. The cells were incubated with $P$. gingivalis for $1 \mathrm{~h}$. The cells were then stained using anti-P. gingivalis antiserum. Each molecule was visualized as follows: GFP and GFP-Rab5 (green) and P. gingivalis (red). Bars in each panel are $10 \mu \mathrm{m}$. (D) Active form of Rab5 colocalizes with P. gingivalis in Ca9-22 cells. Ca9-22 cells were transfected with vectors with inserted genes of GFP alone (control), GFP-Rab5 (S34N) (inactive form of Rab5), and GFP-Rab5 (Q79L) (active form of Rab5). The cells were incubated with $P$. gingivalis for 1 h. Then localization of $P$. gingivalis and Rab5 in the cells was observed by a confocal laser scanning microscope. Each molecule was visualized as follows: GFP and GFP-Rab5 (green) and P. gingivalis (red). Bars in each panel are $10 \mu \mathrm{m}$. (E) Overexpression of the active form of Rab5 increased invasion of P. gingivalis in Ca9-22 cells. Ca9-22 cells were transfected with expression vectors with inserted genes of GFP alone (Control), GFP-Rab5 (S34N) and GFP-Rab5 (Q79L). Viable P. gingivalis in the cells was determined as described in Methods. (Means \pm standard deviations [SD] [ $n=3]$ ). ${ }^{*}, P<0.05$ versus control; ${ }^{*}, P<0.01$ versus GFP alone.

active form of Rab5 in the cell lysates was subjected by a GST-R5BD pull-down assay and was analyzed by Western blotting. Level of the active form of Rab5 induced by TNF- $\alpha$ was not affected by treatments with SB203580 and PD98059. However, treatment with SP60015 decreased the level of the active form 
of Rab5 induced by TNF- (Figure 8A, B). These results suggest that JNK kinase mediates activation of Rab5 by stimulation with TNF- $\alpha$. Furthermore, we invastigated whether NF-kB inhibition affects the activation of Rab5. Ca9-22 cells were transfected with an expression vector with an inserted GFP-Rab5 gene. The transfected cells were preincubated with an NF- $\mathrm{kB}$ inhibitor (PDTC, $5 \mu \mathrm{M}$ ) at $37^{\circ} \mathrm{C}$ for $1 \mathrm{~h}$ and were then incubated with TNF- $\alpha$ for $3 \mathrm{~h}$. The active form of Rab5 in the cell lysates was subjected to a GST-R5BD pulldown assay and was analyzed by Western blotting with anti-GFP antibodies. Treatment with PDTC also did not affect the level of the active form of Rab5 induced by TNF- (Figure 9A, B). These results suggest that

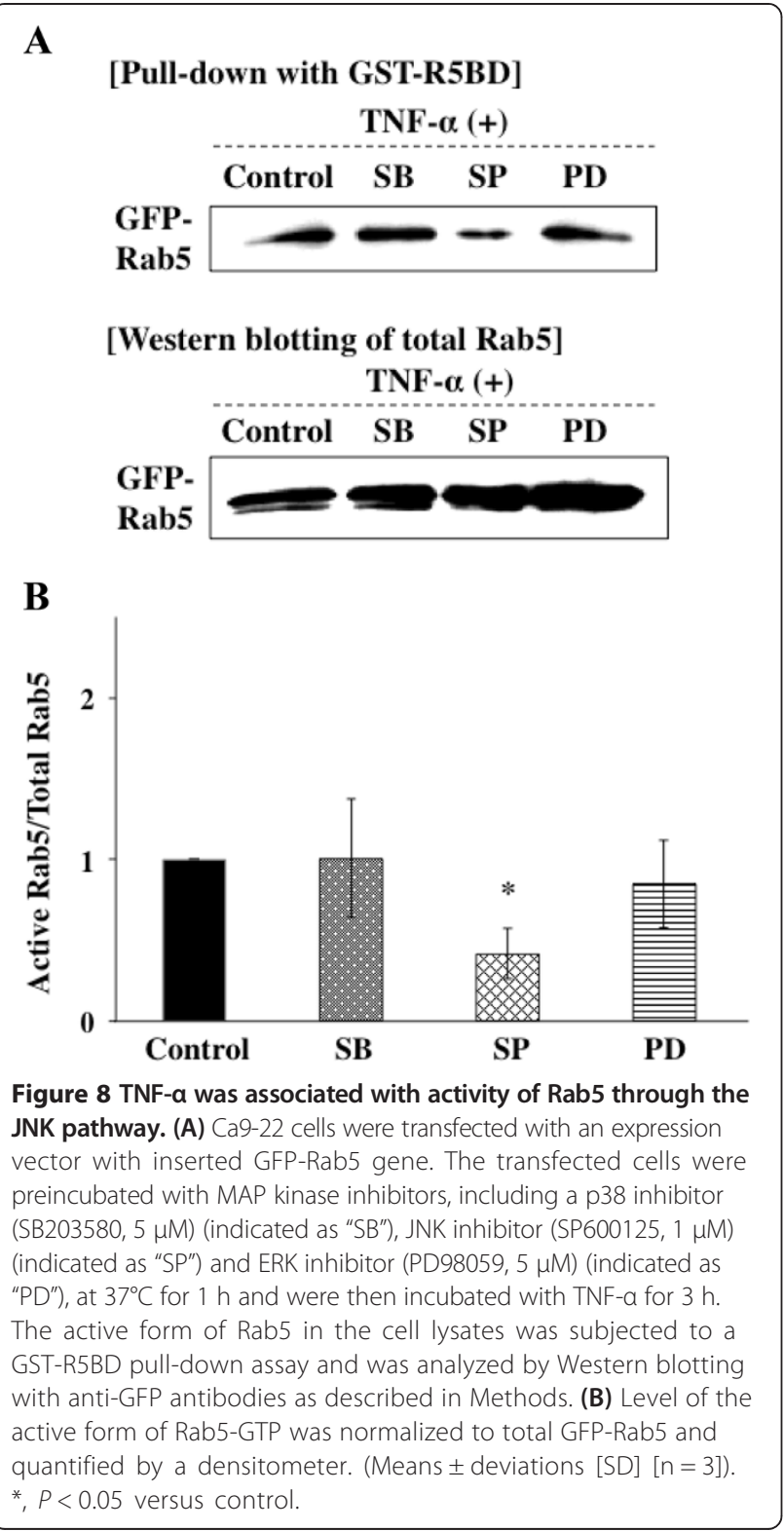

NF- $\mathrm{kB}$ does not mediate activation of Rab5 by stimulation with TNF- $\alpha$.

TNF-a increased colocalization of $P$. gingivalis with ICAM-1 and Rab5

Finally, we examined the relationships among $P$. gingivalis, ICAM-1 and Rab5 in Ca9-22 cells. Ca9-22 cells were transfected with expression vectors with inserted genes

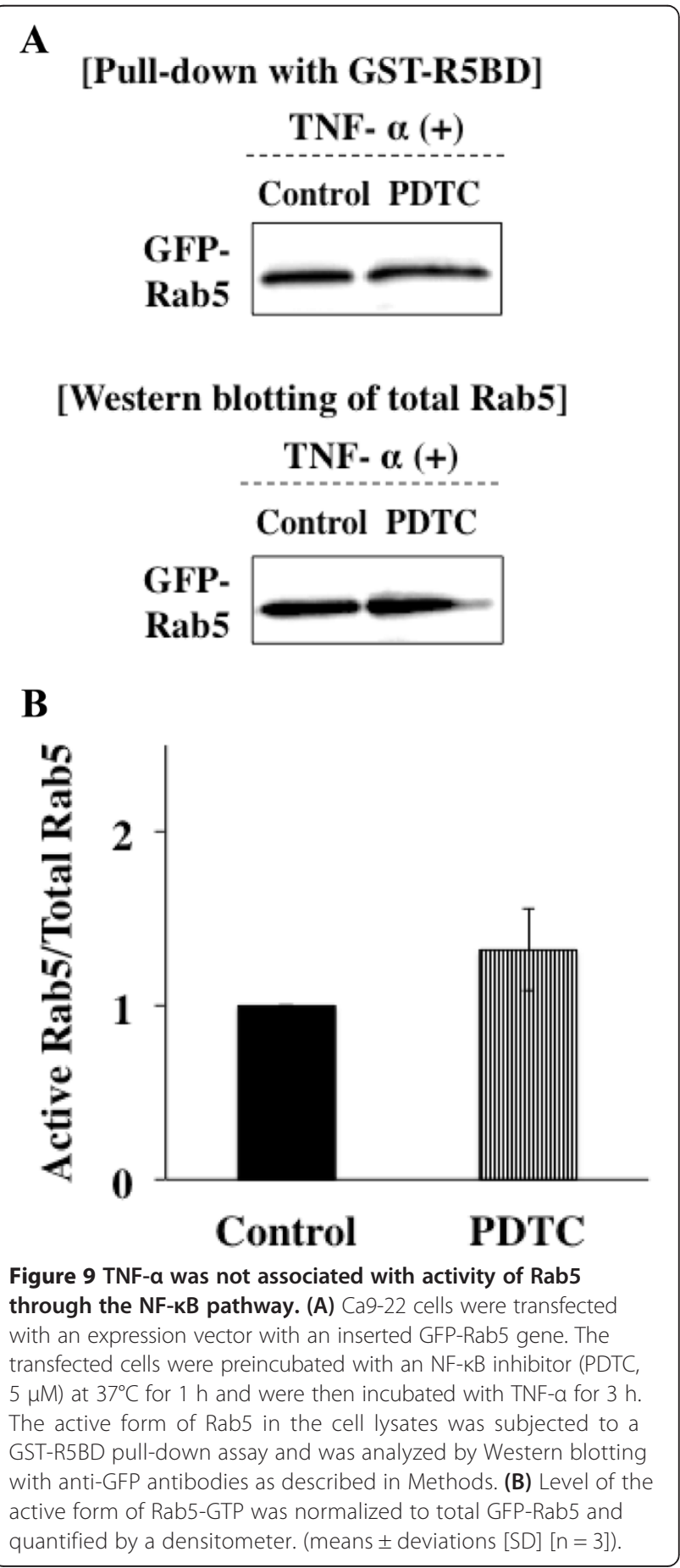


of GFP-Rab5 and were then treated with TNF- $\alpha$ and further incubated with $P$. gingivalis. The cells were then stained using an anti-ICAM-1 antibody and antiserum to $P$. gingivalis whole cells. A small amount of $P$. gingivalis that co-localized with ICAM-1 and GFP-Rab5 was observed in Ca9-22 cells without TNF- $\alpha$ stimulation. However, TNF- $\alpha$ stimulation increased co-localization of P. gingivalis, ICAM-1 and GFP-Rab5 in Ca9-22 cells (Figure 10). These findings suggest that TNF- $\alpha$ affects the localization of Rab5 and ICAM- 1 in cells and may enhance internalization of $P$. gigivalis in the cells.

\section{Discussion}

TNF- $\alpha$ is a potent pleiotropic proinflammatory cytokine and has been implicated in the pathogenesis of periodontitis [12-14]. TNF- $\alpha$ was also shown to activate oral epithelial cells. However, it was not known whether TNF- $\alpha$ affects $P$. gingivalis invasion in epithelial cells. In the present study, we demonstrated for the first time that TNF- $\alpha$ augmented $P$. gingivalis invasion in oral epithelial cells.

In this study, we showed that TNF- $\alpha$ activated Rab5 through JNK but not through p38 and ERK, although TNF- $\alpha$ activates all of them. Activation of JNK is associated with the invasive process of $P$. gingivalis $[1,40]$. Therefore, JNK activated by TNF- $\alpha$ may mediate activation of Rab5 and may enhance internalization of P. gingivalis in cells. Rab5 is an important regulator of early endosome fusion. Therefore, TNF- $\alpha$ may induce formation of early phagosomes by activating Rab5. On the other hand, Bhattacharya et al. [41] demonstrated that cytokines regulate bacterial phagocytosis through induction of Rab GTPases. They showed that IL- 6 specifically induces the expression of Rab5 and activates Salmonella trafficking in cells through ERK activation. On the other hand, IL-12 induced Rab7 expression through p38. Another study showed that activation of p38 MAPK regulates endocytosis by regulating the activity of Rab5 accessory

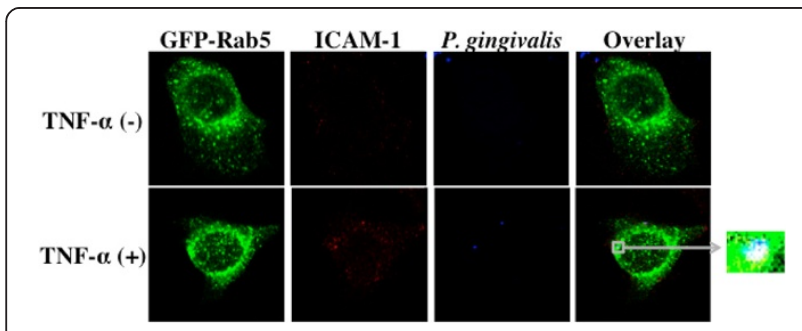

Figure 10 TNF-a increased colocalization of $P$. gingivalis with ICAM-1 and Rab5. Ca9-22 cells were transfected with expression vectors with inserted genes of GFP-Rab5. The cells were treated with TNF-a for $3 \mathrm{~h}$ and were further incubated with $P$. gingivalis for $1 \mathrm{~h}$. The cells were then stained using an anti-ICAM-1 antibody and anti-P. gingivalis antisera. Each molecule was visualized as follows: GFP-Rab5 (green), ICAM-1 (red), and P. gingivalis (blue) proteins such as Rab5-GDI, EEA1, and rabenosyn-5, which are known to regulate membrane transport during endocytosis. Several independent studies have also shown that activation of ERK regulates endocytic traffic of multiple receptor systems, for example, $5-\mathrm{HT}_{1 \mathrm{~A}}$ receptor, $\mathrm{m} 1$ muscarinic receptor, and opioid receptors [42-45]. These findings suggest that activation of different kinases regulates intracellular trafficking and also indicate that the mechanism by which MAPKs regulate endocytosis may differ depending on the stimulants and cells.

As shown in Figure 5B, the p38 inhibitor SB203580 blocked TNF- $\alpha$-augmented $P$. gingivalis invasion in Ca9-22 cells. However, SB203580 did not inhibit the activation of Rab5 despite the fact that internalization of $P$. gingivalis into the cells was partially blocked by knock-down of Rab5a. TNF- $\alpha$ induced ICAM-1 expression through activating ERK/p38 MAPK [46]. Therefore, p38 inhibition suppressed ICAM-1 expression followed by decrease in $P$. gingivalis invasion. On the other hand, Rab5 has three isoforms (A, B, and C) and the isoforms are able to compensate for each other. As we interfered with the expression of Rab5a but not that of Rab5b and 5c, Rab5b and Rab5c, which were not blocked, may compensate the function of Rab5a for bacterial internalization.

P. gingivalis can enter Ca9-22 cells without TNF- $\alpha$ stimulation (Figure 1A). Blockade of the TNF receptor and inhibition of p38 and JNK did not completely inhibit $P$. gingivalis invasion. These results suggest that $P$. gingivalis is also internalized in a TNF- $\alpha$-independent manner. $P$. gingivalis invades gingival epithelial cells without any stimulation to the host cells. $P$. gingivalis fimbriae interact with cell surface molecules such as integrins and the interactions trigger colonization and internalization of the bacteria in various cells $[47,48]$. Furthermore, the trypsin-like cysteine protease gingipain produced by $P$. gingivalis also plays an important role during $P$. gingivalis entry into cells [47]. P. gingivalis can enter host cells by using these molecules without TNF- $\alpha$ stimulation. However, TNF- $\alpha$ is increased in inflamed periodontal tissues and gingival crevicular fluids. In those tissues, $P$. gingivalis invasion is increased, and it promotes persistent infection and avoids immune surveillance. The cellular tropism of $P$. gingivalis depends in part upon the fimbriase of the bacteria and the receptors of the host cell. We used Ca9-22 cells as a model for gingival cell infection. These cells were originally derived from human gingival carcinoma and phenotypically resemble gingival epithelial cells. However, Ca9-22 cells may also express some cell surface receptors that are different from endogenous gingival cells. Thus our experimental system is representative of bacteria-host interactions in vivo, but not a perfect model We have little evidence about that in vivo and further study is needed to make a 
final conclusion concerning the physiological relevance of the phenomena.

Ca9-22 cells expressed TNFR-I but not TNFR-II (Figure 2A). We also ascertained the expression of TNFR-II after treatment with TNF- $\alpha$ in Ca9-22 cells. However, TNF- $\alpha$ did not induce TNFR-II expression in Ca9-22 cells. Therefore, we concluded that the effects of TNF- $\alpha$ are mediated through TNFR-I. TNF- $\alpha$ activates caspases and induces apoptosis in cells. However, C9-22 cells were alive during the experimental periods even after stimulation with TNF- $\alpha$ (Additional file 1: Figure S2). Therefore, we think that the apoptotic activity of TNF- $\alpha$ towards host cells does not affect $P$. gingivalis invasion.

ICAM-1 as well as Rab5 was associated with TNF- $\alpha$ augmented $P$. gingivalis invasion (Figures 6 and 8). Adhesion of $P$. gingivalis to host cells is multimodal and involves the interaction of bacterial cell surface adhesins with receptors expressed on the surfaces of epithelial cells. Adhesion of $P$. gingivalis to host cells is mediated by many extracellular components, including fimbriae, proteases, hemagglutinins, and lipopolysaccharides (LPS). Among the large array of virulence factors produced by $P$. gingivalis, the major fimbriae (FimA), as well as cysteine proteinases (gingipains), contribute to the attachment to and invasion of oral epithelial cells [49,50]. On the other hand, integrins can act as receptors for the integrinbinding proteins of several bacterial species [51-53]. $P$. gingivalis also associates with $\beta 1$ and $\alpha 5 \beta 1$ integrin heterodimers via FimA. $\alpha \mathrm{V} \beta 3$ integrin also mediates fimbriae adhesion to epithelial cells [48]. In addition, carbohydrate chains on epithelial cell membrane glycolipids have been reported to act as receptors for $P$. gingivalis [54]. It has been demonstrated that ICAM-1 is required for the invasion of $P$. gingivalis into human oral epithelial cells [36]. Various cytokines including TNF- $\alpha$ induce expression of ICAM-1 [55,56]. Therefore, ICAM-1 expresion and P. gingivalis invasion in periodontal sites may be associated with the primary stages of the development and progression of chronic periodontitis.

It has been demonstrated that a large number of intracellular bacteria are present in IL-6-treated cells that have an increasing amount of Rab5 [41]. These results indicate that overexpression of Rab5 by cytokines may promote the fusion of bacteria containing phagosomes with early endosomes and thereby inhibit their transport to lysosomes and may help in prolongation of bacterial survival in host cells and thus establish a chronic infection that could exacerbate the immune response. At periodontal sites, such phenomena could occur. Periodontopathic bacteria induce various cytokines including TNF- $\alpha$. It has been shown that of TNF- $\alpha$ is upregulated in periodontitis, e.g., in gingival crevicular fluid [23] and in gingival tissues [24]. Therefore, periodontopathic bacteria including $P$. gingivalis induce the production of cytokines including TNF- $\alpha$ in periodontal tissues. Excess TNF- $\alpha$ in periodontal tissues activates gingival epithelial cells and increases the possibility of $P$. gingivalis invasion in the cells, resulting in persistence of $P$. ginigvalis infection and prolongation of immune responses in periodontal tissues.

\section{Conclusions}

We demonstrated that $P$. ginigvalis invasion into human gingival epithelial cells was enhanced by stimulation with TNF- $\alpha$. TNF- $\alpha$ in periodontal tissues, the production of which is induced by plaque bacteria including $P$. gingivlis and is increased by diabetes, may lead to persistent infection of $P$. ginigvalis and prolongation of immune responses in periodontal tissues.

\section{Methods}

\section{Bacterial strains and growth conditions}

$P$. gingivalis ATCC 33277 was used as a wild-type strain in this study. This strain was grown at $37^{\circ} \mathrm{C}$ under anaerobic conditions on $5 \%$ horse blood agar plates (Poa Media, Eiken Chemical Co., Ltd., Tokyo, Japan) and in $30 \mathrm{mg} / \mathrm{ml}$ trypticase soy broth (BD Biosciences, SanJose, CA) supplemented with $2.5 \mathrm{mg} / \mathrm{ml}$ yeast extract (BD Biosciences), $5 \mu \mathrm{g} / \mathrm{ml}$ hemin and $5 \mu \mathrm{g} / \mathrm{ml}$ menadione. Bacterial growth was monitored by measuring the optical density at $660 \mathrm{~nm}$ (OD660). For invasion assays, an inoculum with an infection ratio (multiplicity of infection [MOI]) of 100 bacteria per cell was added to the cell culture medium.

\section{Cell culture}

The human gingival epithelial cell line Ca9-22 was obtained from RIKEN Bioresource Center (Ibaraki, Japan). Ca9-22 cells were cultured under standard conditions in Eagle's minimal essential medium (E-MEM; Wako Pure Chemical Industries, Ltd., Osaka, Japan) containing 10\% fetal bovine serum (FBS), 1\% penicillin and streptomycin at $37^{\circ} \mathrm{C}$ in a humidified atmosphere of $5 \% \mathrm{CO}_{2}$. The monocytic cell line THP-1 was obtained from Japanese Collection of Research Bioresources Cell Bank (Osaka, Japan). THP-1 cells were cultured under standard conditions in Roswell Park Memorial Institute (RPMI) 1640 Medium (Invitrogen, Carlsbad, CA) containing 10\% FBS, $1 \%$ penicillin and streptomycin at $37^{\circ} \mathrm{C}$ in a humidified atmosphere of $5 \% \mathrm{CO}_{2}$.

\section{Antibodies}

Antibodies were obtained from the following sources: antiserum for $P$. gingivalis whole cells was kindly donated by Dr. Fuminobu Yoshimura (Aichi-gakuin University, Aichi, Japan); mouse monoclonal antibody specific for ICAM-1, goat polyclonal antibody specific for ICAM-1, mouse monoclonal antibody specific for TNFRI, mouse monoclonal antibody specific for TNFRII and mouse 
immunoglobulin G (IgG) (R \& D Systems, Minneapolis, $\mathrm{MN})$; mouse monoclonal antibody specific for Rab5 (BD Biosciences); rabbit polyclonal antibody specific for ICAM-1 (Santa Cruz Biotechnology, Dallas, TX); goat IgG (Alpha Diagnostic Intl. Inc., San Antonio, TX); mouse monoclonal antibody specific for $\beta$-actin (Biovision Inc., Milpitas, CA); anti-rabbit IgG-Alexa 555 and anti-rabbit IgG-Alexa 633 (Invitrogen); mouse monoclonal antibody specific for GFP (Novus Biologicals, Littleton, CO), anti-mouse IgG-HRP, anti-rabbit IgG-HRP and mouse monoclonal antibody specific for $\beta$-actin (Cell Signaling Technology, Danvers, MA).

\section{Vector constructs}

GFP-Rab5Q79L, GFP-Rab5WT, and GFP-Rab5S34N in pcDNA3 constructs were kindly provided by Dr. Yuji Yamamoto (Tokyo University of Agriculture, Tokyo, Japan) $[57,58]$. The GST-R5BD vector was kindly donated by Dr. Guangpu Li (University of Oklahoma Health Science Center, Oklahoma City, OK).

\section{$P$. gingivalis invasion assay}

Invasion of bacteria was quantitated by a standard antibiotic protection assay as described previously [59]. Briefly, Ca9-22 cells were seeded in 12-well flat-bottom culture plates and were incubated overnight before administration of $P$. gingivalis. The cells then were washed twice with phosphate-buffered saline (PBS) and incubated for a further $1 \mathrm{~h}$ in OPTI-MEM (Invitrogen) without antibiotics. The cells were treated with $10 \mathrm{ng} / \mathrm{ml}$ of recombinant human TNF- $\alpha$ (Wako) for $3 \mathrm{~h}$. P. gingivalis suspended in OPTI-MEM was added to the Ca9-22 cells at an MOI of $1: 100$ and further incubated at $37^{\circ} \mathrm{C}$ in $5 \%$ $\mathrm{CO}_{2}$ for $1 \mathrm{~h}$. Unattached bacteria were removed by washing with PBS three times. OPTI-MEM containing $200 \mu \mathrm{g} / \mathrm{ml}$ of metronidazole and $300 \mu \mathrm{g} / \mathrm{ml}$ of gentamicin was added to the plates and they were incubated for $1 \mathrm{~h}$. The cells were washed twice with PBS, and then $1 \mathrm{ml}$ of sterile distilled water per well was added and the cells were suspended persistently by pipetting to disrupt them. The lysates were serially diluted and plated on 5\% horse blood agar plates (Poa Media, Eiken Chemical) and then incubated anaerobically at $37^{\circ} \mathrm{C}$ for 10 days. Colony-forming units (CFU) of invasive $P$. gingivalis in cells were then enumerated.

\section{Silencing of Rab5 gene}

Ca9-22 cells were transfected with 100 pmol siRNA specific for Rab5 (RAB5A-HSS108978, Invitrogen) or control siRNA (Stealth ${ }^{\mathrm{Tm}}$ RNAi Negative Control Medium GC Duplex, Invitrogen) using Lipofectamine 2000 reagent, as described by the manufacturer (Invitrogen). Then, expression of Rab5 in the cells was examined by Western blotting using a monoclonal antibody to Rab5. Next, Rab5 siRNA- transfected Ca9-22 cells were incubated with $P$. gingivalis ATCC $33277(\mathrm{MOI}=100)$ for $1 \mathrm{~h}$. Viable $P$. gingivalis in the cells was determined as described above.

\section{Immunostaining}

Treated Ca9-22 cells were fixed with $4 \%$ formaldehyde for $10 \mathrm{~min}$. Nonspecific binding of antibodies was blocked by incubation with $5 \%$ sheep serum in $10 \mathrm{mM}$ Tris $\mathrm{pH}$ 7.6, $150 \mathrm{mM} \mathrm{NaCl}$, and 0.05\% Tween20 (TBS-T) for $1 \mathrm{~h}$, and then the cells were incubated overnight at $4^{\circ} \mathrm{C}$ with a primary antibody (antiserum for $P$. gingivalis whole cells, mouse monoclonal antibody specific for ICAM-1) in TBS-T. After washing with buffer A (10 mM Tris pH 7.6, $300 \mathrm{mM} \mathrm{NaCl}$, and 0.5\% Tween20) 6 times, the cells were treated with a secondary antibody (anti-rabbit IgG-Alexa 555 or anti-mouse IgG-Alexa 555 and anti-rabbit IgGAlexa 633) in buffer A for $1 \mathrm{~h}$. Cells were then observed by a confocal laser scanning microscope (Leica microsystems, Welzlar, Germany). Some Ca9-22 cells were transfected with vectors containing genes of GFP alone (control), GFPRab5 (S34N) (inactive form of Rab5), and GFP-Rab5 (Q79L) (active form of Rab5). To clarify whether P. gingivalis cells are in the epithelial cells, a $\mathrm{z}$-series with $0.5 \mu \mathrm{m}$ intervals was scanned and images of the $\mathrm{x}-\mathrm{z}$ and $\mathrm{y}-\mathrm{z}$ planes were reconstructed with the orthogonal section tool.

\section{Western blotting}

TNF- $\alpha$-treated and non-treated Ca9-22 cells and THP-1 cells were lysed in SDS-PAGE sample buffer, separated by SDS-PAGE, and transferred onto Immobilon-P Transfer Membranes (Millipore, Billerica, MA). The membranes were blocked with PVDF Blocking Reagent for Can Get Signal (Toyobo) in TBS-T for $1 \mathrm{~h}$ at room temperature and then incubated with antibodies to TNFRI, TNFRII, Rab5 and ICAM- 1 overnight at $4^{\circ} \mathrm{C}$. After washing 3 times with TBS-T, the membranes were incubated with horseradishperoxidase-conjugated anti-rabbit or mouse IgG antibodies

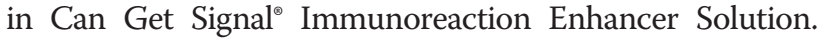
The membranes were washed 3 times with TBS-T and then immunoreactive bands were visualized using ECL Western Blotting detection reagents (GE Healthcare, Uppsala, Sweden) or Immuno Star LD (Wako). The membranes were stripped and probed with anti- $\beta$-actin antibodies as a loading control.

\section{GST-R5BD pull-down assay}

The GST-R5BD pull-down assay was based on the method described by Liu et al. [60]. Ca9-22 cells were transfected with GFP-Rab5 (WT) using Lipofectamine 2000 reagent, as described by the manufacturer (Invitrogen). The transfectants were pretreated with MAP kinase inhibitors, including a p38 inhibitor (SB203580, $5 \mu \mathrm{M}$ ), JNK inhibitor (SP600125, $1 \mu \mathrm{M}$ ), and ERK inhibitor (PD98059, $5 \mu \mathrm{M}$ ) (Calbiochem, San Diego, CA), or with an NF-kB inhibitor 
(PDTC, $5 \mu \mathrm{M}$ ) (Sigma-Aldrich, St. Louis, MO) at $37^{\circ} \mathrm{C}$ for $1 \mathrm{~h}$ followed by stimulating with $10 \mathrm{ng} / \mathrm{ml}$ TNF- $\alpha$ for $3 \mathrm{~h}$. Thereafter, cell extracts were prepared in lysis buffer containing $25 \mathrm{mM}$ HEPES $\mathrm{pH} 7.4,100 \mathrm{mM} \mathrm{NaCl}, 5 \mathrm{mM}$ $\mathrm{MgCl}_{2}, 0.1 \%$ Nonidet P-40, $2 \%$ glycerol, $1 \mathrm{mM}$ dithiothreitol, and protease inhibitors. The cell lysates were centrifuged at $13,000 \times \mathrm{g}$ for $10 \mathrm{~min}$ at $4^{\circ} \mathrm{C}$, and then the supernatants were incubated with $20 \mu \mathrm{l}$ of GSTR5BD bound to glutathione-Sepharose $4 \mathrm{~B}$ beads for $10 \mathrm{~min}$ at $4^{\circ} \mathrm{C}$ under rotation. Thereafter, beads were collected and washed 3 times with lysis buffer. Samples were re-suspended in SDS sample buffer and analyzed by Western blotting.

\section{Measurement of cell viability}

Cell viability was assessed by the trypan blue staining assay. Ca9-22 cells were preincubated with wortmannin (Wort, $300 \mathrm{nM}$ ) for $3 \mathrm{~h}$ or with actinomycin D (Act D, $1 \mu \mathrm{g} / \mathrm{ml}$ ), cycloheximide (CHX, $1 \mu \mathrm{g} / \mathrm{ml}$ ), NF-kB inhibitor (PDTC, $5 \mu \mathrm{M}$ ), MAP kinase inhibitors, including a p38 inhibitor (SB203580, $5 \mu \mathrm{M}$ ), JNK inhibitor (SP600125, $1 \mu \mathrm{M}$ ) and ERK inhibitor (PD98059, $5 \mu \mathrm{M}$ ), at $37^{\circ} \mathrm{C}$ for $1 \mathrm{~h}$ and were then incubated with TNF- $\alpha$ for $3 \mathrm{~h}$. Viability of the cells was determined by an exclusion test with trypan blue. Each measurement was repeated three times independently. Those compounds were not toxic to the cells. (Additional file 2: Figure S1).

\section{Statistical analyses}

All experiments were performed in triplicate for each condition and repeated at least three times. Statistical analyses were performed using an unpaired Student's $t$ test. Multiple comparisons were performed by oneway analysis of variance and the Bonferroni or Dunn method, with results presented as the mean \pm standard deviation. P-values less than 0.05 were considered statistically significant.

\section{Additional files}

Additional file 1: Figure S2. Numbers of alive $P$. gingivalis bacteria in Ca9-22 cell cultures. The numbers of intracellular and extracellular P. gingivalis were determined in Ca9-22 cells. Ca9-22 cells were treated with $10 \mathrm{ng} / \mathrm{ml}$ TNF-a for $3 \mathrm{~h}$. The cells were infected with P. gingivalis (MOI 100) for $1 \mathrm{~h}$. The cells were further cultured in media containing antibiotics for various time periods to kill extracellular bacteria. Then the cells were incubated in antibiotics-free media for $0-48 \mathrm{~h}$, and the numbers of intracellular and extracellular bacteria were determined. The assays were carried out in triplicate as described in Methods. * and ${ }^{* *}$, significantly different $(P<0.05$ and $P<0.01$, respectively) from the mean value for TNF (-). Error bars indicate standard errors of the means.

Additional file 2: Figure S1. Cytotoxicity of chemical compounds used in this study. Ca9-22 cells were preincubated with wortmannin (Wort, 300 nM) for $3 \mathrm{~h}$ or with actinomycin D (Act D, $1 \mu \mathrm{g} / \mathrm{ml}$ ), cycloheximide (CHX $1 \mu \mathrm{g} / \mathrm{ml}$ ), an NF-KB inhibitor (PDTC, $5 \mu \mathrm{M}$ ) and MAP kinase inhibitors, including a p38 inhibitor (SB203580, 5 HM) (indicated as "SB"), JNK inhibitor (SP600125, $1 \mu \mathrm{M}$ ) (indicated as "SP") and ERK inhibitor
(PD98059, $5 \mu \mathrm{M}$ ) (indicated as "PD"), at $37^{\circ} \mathrm{C}$ for $1 \mathrm{~h}$ and were then incubated with TNF-a for $3 \mathrm{~h}$. Viability of the cells was determined by an exclusion test with trypan blue.

\section{Competing interests}

The authors of this study have no competing interest to report.

\section{Authors' contributions}

YK conceived the study, performed the experiments, and drafted the manuscript. MH, SS, and TK supported the molecular and cellular studies. RI, IY and NI supported bacteria-related studies. TN and KM participated in the study, supervised the experiments, and designed and critically revised the manuscript. All authors read and approved the final manuscript.

\section{Acknowledgements}

This work was supported by a Grant-in-Aid for Scientific Research B (to K.M.) and a Grant-in-Aid for Challenging Exploratory Research (to K.M.) from the Ministry of Education, Culture, Sports, Science and Technology, Japan. We thank Dr. Y. Yamamoto (Tokyo University of Agriculture, Tokyo, Japan) for GFP-Rab5Q79L, GFP-Rab5WT and GFP-Rab5S34N in pcDNA3 constructs, Dr. G. Li (University of Oklahoma Health Science Center, Oklahoma City, USA) for GST-R5BD constructs, Dr. F. Yoshimura (Aichi-gakuin University, Aichi, Japan) for antiserum for $P$. gingivalis whole cells constructs.

\section{Author details}

'Department of Oral Disease Research, National Center of Geriatrics and Gerontology, Obu, Aichi 747-8511, Japan. ²Department of Periodontology, Aichigakuin University, Nagoya, Aichi, Japan.

Received: 3 February 2014 Accepted: 19 August 2014 Published: 3 September 2014

\section{References}

1. Zhang W, Ju J, Rigney T, Tribble G: Integrin alpha5beta1-fimbriae binding and actin rearrangement are essential for Porphyromonas gingivalis invasion of osteoblasts and subsequent activation of the JNK pathway. BMC Microbiol 2013, 13:5

2. Stafford P, Higham J, Pinnock A, Murdoch C, Douglas CW, Stafford GP, Lambert DW: Gingipain-dependent degradation of mammalian target of rapamycin pathway proteins by the periodontal pathogen Porphyromonas gingivalis during invasion. Mol Oral Microbiol 2013, 28(5):366-378

3. Inaba H, Sugita H, Kuboniwa M, Iwai S, Hamada M, Noda T, Morisaki I, Lamont RJ, Amano A: Porphyromonas gingivalis promotes invasion of oral squamous cell carcinoma through induction of proMMP9 and its activation. Cell Microbiol 2014, 16(1):131-145

4. Lamont RJ, Jenkinson HF: Life below the gum line: pathogenic mechanisms of Porphyromonas gingivalis. Microbiol Mol Biol Rev 1998, 62(4):1244-1263.

5. Lamont RJ, Yilmaz O: In or out: the invasiveness of oral bacteria. Periodontol 2000 2002, 30:61-69.

6. Hutagalung $\mathrm{AH}$, Novick PJ: Role of Rab GTPases in membrane traffic and cell physiology. Physiol Rev 2011, 91(1):119-149.

7. Mukherjee K, Parashuraman S, Raje M, Mukhopadhyay A: SopE acts as an Rab5-specific nucleotide exchange factor and recruits non-prenylated Rab5 on Salmonella-containing phagosomes to promote fusion with early endosomes. J Biol Chem 2001, 276(26):23607-23615.

8. Mallo GV, Espina M, Smith AC, Terebiznik MR, Aleman A, Finlay BB, Rameh LE, Grinstein S, Brumell JH: SopB promotes phosphatidylinositol 3-phosphate formation on Salmonella vacuoles by recruiting Rab5 and Vps34. J Cell Biol 2008, 182(4):741-752.

9. Madan R, Krishnamurthy G, Mukhopadhyay A: SopE-mediated recruitment of host Rab5 on phagosomes inhibits Salmonella transport to lysosomes. Methods Mol Biol 2008, 445:417-437.

10. Clemens DL, Lee BY, Horwitz MA: Deviant expression of Rab5 on phagosomes containing the intracellular pathogens Mycobacterium tuberculosis and Legionella pneumophila is associated with altered phagosomal fate. Infect Immun 2000, 68(5):2671-2684.

11. Alvarez-Dominguez C, Barbieri AM, Beron W, Wandinger-Ness A, Stahl PD: Phagocytosed live Listeria monocytogenes influences Rab5-regulated 
in vitro phagosome-endosome fusion. J Biol Chem 1996, 271(23):13834-13843.

12. Preshaw PM, Taylor J: How has research into cytokine interactions and their role in driving immune responses impacted our understanding of periodontitis? J Clin Periodontol 2011, 38(Suppl 11):60-84

13. Deo V, Bhongade ML: Pathogenesis of periodontitis: role of cytokines in host response. Dent Today 2010, 29(9):60-62. 64-66; quiz 68-69.

14. Andrukhov O, Ulm C, Reischl H, Nguyen PQ, Matejka M, Rausch-Fan X: Serum cytokine levels in periodontitis patients in relation to the bacterial load. J Periodontol 2011, 82(6):885-892.

15. El Oudi M, Bouguerra C, Aouni Z, Mazigh C, Bellaaj R, Machghoul S: Homocysteine and inflammatory biomarkers plasma levels, and severity of acute coronary syndrome. Ann Biol Clin (Paris) 2011, 69(2):175-180.

16. Goldberg RB: Cytokine and cytokine-like inflammation markers, endothelial dysfunction, and imbalanced coagulation in development of diabetes and its complications. J Clin Endocrinol Metab 2009, 94(9):3171-3182.

17. Gotsman I, Stabholz A, Planer D, Pugatsch T, Lapidus L, Novikov Y, Masrawa S, Soskolne A, Lotan C: Serum cytokine tumor necrosis factor-alpha and interleukin- 6 associated with the severity of coronary artery disease: indicators of an active inflammatory burden? Isr Med Assoc J 2008, 10(7):494-498.

18. Spranger J, Kroke A, Mohlig M, Hoffmann K, Bergmann MM, Ristow M, Boeing H, Pfeiffer AF: Inflammatory cytokines and the risk to develop type 2 diabetes: results of the prospective population-based European Prospective Investigation into Cancer and Nutrition (EPIC)-Potsdam Study. Diabetes 2003, 52(3):812-817.

19. Gigante A, Gasperini ML, Afeltra A, Barbano B, Margiotta D, Cianci R, De Francesco I, Amoroso A: Cytokines expression in SLE nephritis. Eur Rev Med Pharmacol Sci 2011, 15(1):15-24.

20. McDevitt $H$, Munson S, Ettinger R, Wu A: Multiple roles for tumor necrosis factor-alpha and lymphotoxin alpha/beta in immunity and autoimmunity. Arthritis Res 2002, 4(Suppl 3):S141-S152.

21. Jing $Y$, Ma N, Fan T, Wang C, Bu X, Jiang G, Li R, Gao L, Li D, Wu M, Wei L: Tumor necrosis factor-alpha promotes tumor growth by inducing vascular endothelial growth factor. Cancer Invest 2011, 29(7):485-493.

22. Grimm M, Lazariotou M, Kircher $S$, Hofelmayr A, Germer CT, von Rahden BH, Waaga-Gasser AM, Gasser M: Tumor necrosis factor-alpha is associated with positive lymph node status in patients with recurrence of colorectal cancer-indications for anti-TNF-alpha agents in cancer treatment. Cell Oncol 2011, 34(4):315-326.

23. Kurtis B, Tuter G, Serdar M, Akdemir P, Uygur C, Firatli E, Bal B: Gingival crevicular fluid levels of monocyte chemoattractant protein-1 and tumor necrosis factor-alpha in patients with chronic and aggressive periodontitis. J Periodontol 2005, 76(11):1849-1855.

24. Gorska R, Gregorek H, Kowalski J, Laskus-Perendyk A, Syczewska M, Madalinski K: Relationship between clinical parameters and cytokine profiles in inflamed gingival tissue and serum samples from patients with chronic periodontitis. J Clin Periodontol 2003, 30(12):1046-1052.

25. Havemose-Poulsen A, Sorensen LK, Stoltze K, Bendtzen K, Holmstrup P: Cytokine profiles in peripheral blood and whole blood cell cultures associated with aggressive periodontitis, juvenile idiopathic arthritis, and rheumatoid arthritis. J Periodontol 2005, 76(12):2276-2285.

26. Bradley JR: TNF-mediated inflammatory disease. J Pathol 2008 214(2):149-160

27. Berk BC, Abe Jl, Min W, Surapisitchat J, Yan C: Endothelial atheroprotective and anti-inflammatory mechanisms. Ann N Y Acad Sci 2001, 947:93-109. discussion 109-111.

28. Yehuda H, Szuchman-Sapir A, Khatib S, Musa R, Tamir S: Human atherosclerotic plaque lipid extract promotes expression of proinflammatory factors in human monocytes and macrophage-like cells. Atherosclerosis 2011, 218(2):339-343

29. Schett G: Effects of inflammatory and anti-inflammatory cytokines on the bone. Eur J Clin Invest 2011, 41(12):1361-1366.

30. Ungvari Z, Csiszar A, Edwards JG, Kaminski PM, Wolin MS, Kaley G, Koller A: Increased superoxide production in coronary arteries in hyperhomocysteinemia: role of tumor necrosis factor-alpha, NAD $(P) H$ oxidase, and inducible nitric oxide synthase. Arterioscler Thromb Vasc Biol 2003, 23(3):418-424.

31. Sandros J, Karlsson C, Lappin DF, Madianos PN, Kinane DF, Papapanou PN: Cytokine responses of oral epithelial cells to Porphyromonas gingivalis infection. J Dent Res 2000, 79(10):1808-1814.
32. Vandenabeele $P$, Declercq W, Beyaert R, Fiers W: Two tumour necrosis factor receptors: structure and function. Trends Cell Biol 1995, 5(10):392-399.

33. Tartaglia LA, Goeddel DV: Two TNF receptors. Immunol Today 1992, 13(5):151-153.

34. Hannigan MO, Huang CK, Wu DQ: Roles of PI3K in neutrophil function. Curr Top Microbiol Immunol 2004, 282:165-175.

35. Nizamutdinova IT, Jeong JJ, Xu GH, Lee SH, Kang SS, Kim YS, Chang KC, Kim HJ: Hesperidin, hesperidin methyl chalone and phellopterin from Poncirus trifoliata (Rutaceae) differentially regulate the expression of adhesion molecules in tumor necrosis factor-alpha-stimulated human umbilical vein endothelial cells. Int Immunopharmacol 2008, 8(5):670-678

36. Tamai $R$, Asai $Y$, Ogawa T: Requirement for intercellular adhesion molecule 1 and caveolae in invasion of human oral epithelial cells by Porphyromonas gingivalis. Infect Immun 2005, 73(10):6290-6298.

37. Bucci C, Lutcke A, Steele-Mortimer O, Olkkonen VM, Dupree P, Chiariello M, Bruni CB, Simons K, Zerial M: Co-operative regulation of endocytosis by three Rab5 isoforms. FEBS Lett 1995, 366(1):65-71.

38. Sturgill-Koszycki S, Schaible UE, Russell DG: Mycobacterium-containing phagosomes are accessible to early endosomes and reflect a transitional state in normal phagosome biogenesis. EMBO J 1996, 15(24):6960-6968.

39. Alvarez-Dominguez C, Stahl PD: Increased expression of Rab5a correlates directly with accelerated maturation of Listeria monocytogenes phagosomes. J Biol Chem 1999, 274(17):11459-11462.

40. Watanabe K, Yilmaz O, Nakhjiri SF, Belton CM, Lamont RJ: Association of mitogen-activated protein kinase pathways with gingival epithelial cell responses to Porphyromonas gingivalis infection. Infect Immun 2001 69(11):6731-6737.

41. Bhattacharya M, Ojha N, Solanki S, Mukhopadhyay CK, Madan R, Patel N, Krishnamurthy G, Kumar S, Basu SK, Mukhopadhyay A: IL-6 and IL-12 specifically regulate the expression of Rab5 and Rab7 via distinct signaling pathways. EMBO J 2006, 25(12):2878-2888.

42. Della Rocca GJ, Mukhin Y, Garnovskaya MN, Daaka Y, Clark GJ, Luttrell LM, Lefkowitz RJ, Raymond JR: Serotonin 5-HT1A receptor-mediated Erk activation requires calcium/calmodulin-dependent receptor endocytosis. J Biol Chem 1999, 274(8):4749-4753.

43. Vogler O, Nolte B, Voss M, Schmidt M, Jakobs KH, van Koppen CJ: Regulation of muscarinic acetylcholine receptor sequestration and function by beta-arrestin. J Biol Chem 1999, 274(18):12333-12338.

44. Whistler $J$, von Zastrow M: Dissociation of functional roles of dynamin in receptor-mediated endocytosis and mitogenic signal transduction. J Biol Chem 1999, 274(35):24575-24578.

45. McPherson PS, Kay BK, Hussain NK: Signaling on the endocytic pathway. Traffic 2001, 2(6):375-384

46. Nizamutdinova IT, Oh HM, Min YN, Park SH, Lee MJ, Kim JS, Yean MH, Kang SS, Kim YS, Chang KC, Kim HJ: Paeonol suppresses intercellular adhesion molecule- 1 expression in tumor necrosis factor-alpha-stimulated human umbilical vein endothelial cells by blocking p38, ERK and nuclear factor-kappaB signaling pathways. Int Immunopharmacol 2007, 7(3):343-350.

47. Amano A: Bacterial adhesins to host components in periodontitis. Periodontol 2000 2010, 52(1):12-37.

48. Nakagawa I, Amano A, Kuboniwa M, Nakamura T, Kawabata S, Hamada S: Functional differences among FimA variants of Porphyromonas gingivalis and their effects on adhesion to and invasion of human epithelial cells. Infect Immun 2002, 70(1):277-285.

49. Chen T, Nakayama K, Belliveau L, Duncan MJ: Porphyromonas gingivalis gingipains and adhesion to epithelial cells. Infect Immun 2001, 69(5):3048-3056.

50. Weinberg A, Belton CM, Park Y, Lamont RJ: Role of fimbriae in Porphyromonas gingivalis invasion of gingival epithelial cells. Infect Immun 1997, 65(1):313-316

51. Watarai M, Funato S, Sasakawa C: Interaction of Ipa proteins of Shigella flexneri with alpha5beta1 integrin promotes entry of the bacteria into mammalian cells. J Exp Med 1996, 183(3):991-999.

52. Roger $\mathrm{P}$, Puchelle E, Bajolet-Laudinat $\mathrm{O}$, Tournier JM, Debordeaux C, Plotkowski MC, Cohen JH, Sheppard D, de Bentzmann S: Fibronectin and alpha5beta1 integrin mediate binding of Pseudomonas aeruginosa to repairing airway epithelium. Eur Respir J 1999, 13(6):1301-1309.

53. Ishibashi $Y$, Relman DA, Nishikawa A: Invasion of human respiratory epithelial cells by Bordetella pertussis: possible role for a filamentous hemagglutinin Arg-Gly-Asp sequence and alpha5beta1 integrin. Microb Pathog 2001, 30(5):279-288. 
54. Hellstrom U, Hallberg EC, Sandros J, Rydberg L, Backer AE: Carbohydrates act as receptors for the periodontitis-associated bacterium Porphyromonas gingivalis: a study of bacterial binding to glycolipids. Glycobiology 2004 14(6):511-519.

55. Krunkosky TM, Fischer BM, Akley NJ, Adler KB: Tumor necrosis factor alpha (TNF alpha)-induced ICAM-1 surface expression in airway epithelial cells in vitro: possible signal transduction mechanisms. Ann N Y Acad Sci 1996, 796:30-37.

56. Hashimoto M, Shingu M, Ezaki I, Nobunaga M, Minamihara M, Kato K, Sumioki H: Production of soluble ICAM-1 from human endothelial cells induced by IL-1 beta and TNF-alpha. Inflammation 1994, 18(2):163-173.

57. Hagiwara M, Shirai Y, Nomura R, Sasaki M, Kobayashi K, Tadokoro T, Yamamoto Y: Caveolin-1 activates Rab5 and enhances endocytosis through direct interaction. Biochem Biophys Res Commun 2009, 378(1):73-78.

58. Hagiwara M, Shinomiya H, Kashihara M, Kobayashi K, Tadokoro T, Yamamoto Y: Interaction of activated Rab5 with actin-bundling proteins, $\mathrm{L}$ - and T-plastin and its relevance to endocytic functions in mammalian cells. Biochem Biophys Res Commun 2011, 407(3):615-619.

59. Lamont R, Chan A, Belton CM, Izutsu KT, Vasel D, Weinberg A: Porphyromonas gingivalis invasion of gingival epithelial cells. Infect Immun 1995, 63(10):3878-3885.

60. Liu J, Lamb D, Chou MM, Liu YJ, Li G: Nerve growth factor-mediated neurite outgrowth via regulation of Rab5. Mol Biol Cell 2007, 18(4):1375-1384.

doi:10.1186/s12866-014-0229-z

Cite this article as: Kato et al: TNF-a augmented Porphyromonas gingivalis invasion in human gingival epithelial cells through Rab5 and ICAM-1. BMC Microbiology 2014 14:229.

\section{Submit your next manuscript to BioMed Central and take full advantage of:}

- Convenient online submission

- Thorough peer review

- No space constraints or color figure charges

- Immediate publication on acceptance

- Inclusion in PubMed, CAS, Scopus and Google Scholar

- Research which is freely available for redistribution 